\title{
PURCHASING POWER PARITY AND INTEREST PARITY IN THE LABORATORY
}

\author{
ERIC O'N. FISHER* \\ The Ohio State University
}

\begin{abstract}
This paper analyses purchasing power parity and uncovered interest parity in the laboratory. It finds strong evidence that purchasing power parity, covered interest parity, and uncovered interest parity hold. Subjects are endowed with an intrinsically useless (green) currency that can be used to purchase another useless (red) currency. Green goods can be bought only with green currency, and red goods can be bought only with red currency. The foreign exchange markets are organised as call markets. In the treatment analysing purchasing power parity, the price of the red good varies. In a second treatment, the interest rate on red currency varies. In a third treatment, the interest rate on red currency varies, and the price of the red good is random.
\end{abstract}

\section{INTRODUCTION}

One of the central ideas in international finance is the notion that a currency's exchange rate is fundamentally related to its purchasing power. This observation was first made by Cassel (1916), and, in its current incarnation, it has given rise in the last decade to a cottage industry applying unit root tests to field data on price indices and exchange rates. Indeed, there is an old saying that goes, 'Scratch an international economist, and you will find underneath someone who believes in purchasing power parity.'

This paper takes a new approach to the old question of whether the buying power of a currency is indeed the fundamental determinant of its rate of exchange. It describes three different experimental treatments that analyse purchasing power parity, covered interest parity, and uncovered interest parity. In essence, this paper analyses laboratory economies in which a country's inflation rate and its interest rate are the experimenter's control variables. In sharp contrast with much of the modern econometric literature, this paper presents strong evidence in support of (two versions of) purchasing power parity and both covered and uncovered interest parity.

Field data on international financial markets are really quite abundantly available. Indeed, there have been studies of minute-to-minute changes in foreign exchange markets and

* The author thanks the National Science Foundation for grant 9870874 . He is grateful for the hospitality of Osaka University's Institute for Social and Economic Research, where these ideas had their gestation. An anonymous referee and seminar participants at Monash University's Prato Conference on International Financial Markets, the University of Kentucky, The Ohio State University, and the University of Arkansas gave very helpful comments. Namita Bafana provided exemplary research assistance. The author will make available at no charge the data and the instructions from each of the experiments described below. 
important analyses of their hourly changes. ${ }^{1}$ So why should an international economist even be interested in experiments? What is the appeal of investigating simple ideas in international finance in a controlled environment?

Of course these rhetorical questions are really straw men. In an efficient market, there are sound theoretical reasons to posit that changes in the nominal exchange rate are a martingale, and there is overwhelming empirical evidence in support of this observation. Thus the nominal exchange rate is fundamentally non-stationary, a fact that makes statistical inference from field data a bit complicated. Also, any theory of asset-price formation must deal with the effect of heterogeneous expectations about a non-stationary stochastic process. Hence, an econometric analysis of field data that rejects the null hypothesis of purchasing power parity is really a repudiation of (at least) a tripartite joint hypothesis. The evidence may indicate that: (1) inflation differentials do not explain nominal exchange rate changes; (2) measured historical inflation rates do not fully capture expected inflation; or (3) agents' decision rules for trading foreign exchange may not be stationary.

Setting up a controlled experiment at least allows the economist to know the true inflation process $^{2}$ because the experimenter actually 'creates' inflation differentials as treatment variables. Also, the relevant price indices are never measured with error, since the experimenter can create a 'basket of traded goods' that is quite simple indeed. It is admittedly never easy to divine subjects' trading rules, but it is quite possible to create simple trading mechanisms that are replicated in static environments.

This aspect of experimental design is perhaps the greatest advantage of analysing elements of international finance in the laboratory. Field data would be much easier to interpret if international markets were actually stationary stochastic environments. But as a practical matter, the failure of a centuries-old financial institution like Barings Bank because of the putative actions of a single rogue trader shorting derivative securities in Singapore is by its very nature a one-off event. Thus field foreign exchange markets are-much to the chagrin of many international economists - fundamentally non-stationary. And creating simple stationary environments is where the experimentalist can indeed make hay.

Surprisingly, there have been only three papers in experimental international finance. ${ }^{3}$ The first is by Arifovic (1996). This author used a fundamentally non-stationary environment (the subjects did not even know when the experiment was going to end) based on a model that states that the stationary nominal (and real) exchange rate is indeterminate. Arifovic had subjects trade one homogeneous goods for two different currencies. The main finding of this research is that the exchange exhibits cycles, but this is probably an artifact of how the author implements the overlapping generations framework that is at the heart of the model.

The second article is by Noussair, Plott, and Riezman (1997), and their experimental designs are much closer in spirit to those in this paper. The subjects in those experiments were either producers or consumers. Three consumers and three producers lived in Country

1 Engle, Ito, and Lin (1990) is a fine example; those authors exploit the fact that foreign exchange markets are essentially open around the clock somewhere on the globe.

${ }_{2}$ This consideration is not a trivial matter for field data. The modern error of floating exchange ratesthe period from which most data are drawn for econometric analyses of purchasing power parity-has been a time of the secular inflation followed perhaps by a long-term disinflation. Thus it is not even obvious if inflation rates, let alone measured prices themselves, are stationary. In the parlance of modern time series econometrics, (the logarithm of) price indices may actually be integrated of order two.

${ }^{3}$ Fisher (forthcoming) discusses the wider literature on experiments with arbitrage across assets. 
A, and an equal number of counterparts lived in Country B. Suppliers and demanders could produce two different goods: good $x$ and good $y$. Because of an idiosyncrasy in the computer software, only one foreign exchange market was open: that for the currency A inside Country B. Thus a resident of Country A wanting to buy (perhaps cheaper) goods from Country B had to go to Country B (i.e. page between computer screens) and sell some of the currency with which he was endowed (currency A) against currency B. In particular, suppliers in Country A could not earn foreign exchange; they could only sell goods against their local currency. The functioning of the goods markets in these experiments was a bit problematic; the conceptual difficulties were perhaps best summarised by the statement 'Thus imports were allowed but exports were not' (Noussair, Plott and Riezman, 1997, p. 829). These frictions created adverse conditions in the goods markets; the authors state that the market for one of the two goods did not function well. Still, the authors found that the predicted value for the exchange rate was fairly accurate, even though purchasing power parity did not hold. Since the law of one price was violated in the market with the greatest friction, a simple notion of purchasing power parity was generally rejected. It may be more accurate to summarise these results by stating the general predictions of the competitive model in an economy with two locations did not hold uniformly; one of those predictions would be that purchasing power parity was true.

The third paper in this literature is by Fisher and Kelly (2000). They construct a simple design for analysing asset prices in non-stationary environments. Their designs consisted of markets for two largely identical dividend-bearing assets. These experiments were based upon the notion that the crux of any theory of international exchange rate determination is really an analysis of cross-asset arbitrage. They found that bubbles arose uniformly in the markets for each individual asset, but that the cross-asset price - the exchange rate-was actually very well behaved. Because the bubbles in the two asset markets were almost perfectly correlated, simple aspects of exchange rate theory did well enough, even in a nonstationary environment.

The experiments in this paper are more elegant than those in Noussair, Plott, and Riezman's because the goods markets are very simple indeed. Green goods are available in elastic supply at a constant green-currency price in every period, and red goods are available in elastic supply at a red-currency price that is announced at the beginning of each period. In essence, the experimenter creates the supply side of the goods market, probably one of the confounding aspects of Noussair, Riezman, and Plott's designs. Also, the foreign exchange market is very transparent. Every subject is endowed with an ample supply of green currency, more than sufficient for the liquidity needs of the entire session. But, in each round, there is a fixed (and thus perfectly inelastic) supply of red currency sold in a call market. In essence, the experimenter creates the supply sides of the goods markets and the foreign exchange markets.

The simplicity of the designs allow for easy tests of interest parity. It is possible to create replications of the simplest possible dynamic environment: a two-period framework. Green currency bears no interest, but red currency bears interest between sub-period A and subperiod $\mathrm{B}$ in each round. The rate of return on red-currency is a treatment variable, but red currency is held over only from sub-period A to sub-period B in each round. Then it must be spent to buy red goods. Hence each session essentially replicates ten times over the notion that the two different currencies have disparate and variable own rates of return. This aspect of the design creates strong results that corroborate simple theories of interest parity. Still, in all treatments, the experimenter creates the supply side of the (perfectly inelastic) foreign exchange market and the (perfectly elastic) goods markets. 
The treatment where the own-currency price of each good is known with certainty allows one to examine how well covered interest parity fares because there is no inflation risk from holding an open position in either currency. The treatment in which the price of the red good is random allows one to test uncovered interest parity because buying red currency in subperiod $\mathrm{A}$ is indeed risky. Comparing the results from the treatment where goods prices are known with certainty with those from the treatment where some goods price is random allows one to make inference about the risk premium for foreign exchange.

The rest of this paper is organised as follows. In the second section, we present the four hypotheses at the foundation of the analysis. The third section describes the designs of the treatments, and the fourth section describes the procedures used in the experiments. The fifth section discusses the results and presents the data in a largely graphical analysis. The sixth section gives some brief conclusions and ends with an exhortation to more experimental research in international economics.

\section{HyPOTHESES}

Let $e_{t}$ be the green asset price of a unit of red currency at time $t$. Also, let $p_{t}$ be the price in units of green currency of a green good and $p_{t}^{*}$ be the price in units of red currency of a red good, both measured at time $t$. Of course, $p_{t}$ and $p_{t}^{*}$ are treatment variables, and the statistical analysis focuses on $e_{t}$ from the different treatments. The simplest hypothesis is called the relative version of purchasing power parity, and it is expressed as the notion that $q_{t} \equiv e_{t} p_{t}^{*} / p_{t}$ is independent of time

\section{Hypothesis 1: The relative version of purchasing power parity holds.}

The green and red goods have induced valuations according to their redemption values. Let $v_{g}$ be the (dollar) redemption value of the green good and $v_{r}$ be the (dollar) redemption value of the red good. Then the real exchange rate $q_{t}$ ought to be constant and reflect the ratio $v_{r} / v_{g}$ exactly.

\section{Hypothesis 2: The absolute version of purchasing power parity holds.}

Another fundamental arbitrage relationship has to do with assets that bear interest. If the interest rate on red currency is higher than that on green currency, then the read exchange rate ought to depreciate according to this interest differential. In the jargon of international finance, this is relationship is called interest parity. In financial markets in the field holding an open position in a currency for any substantial time gives rise to inflation risk. That is why most foreign exchange transactions are swaps involving essentially offsetting positions at different maturities. The derived forward premium automatically reflects the interest differential when a position is not subject to inflation risk, an arbitrage relationship called covered interest parity. We examine:

\section{Hypothesis 3: Covered interest parity holds.}

The analog of covered interest parity is that the expected depreciation of the spot rate is 
determined by differences in expected inflation between countries, even when an open position is subject to inflation risk.

Hypothesis 4: Uncovered interest parity holds.

\section{EXPERIMENTAL DESIGNS}

The most important element of the designs is that green or red currency is intrinsically worthless; a currency only has value because it can be used to purchase a good, which then can be redeemed for cash at the end of the session. This element of the designs imposes a strong cash-in-advance constraint for each currency. Some might argue that this aspect of the designs is unrealistic because only a very small fraction of trading in foreign exchange markets in the field occurs in order to finance imports. On the other hand, imposing two simple cash-in-advance constraints is the norm in a large body of the theoretical literature in international monetary economics.

In each treatment, green currency was exchanged for red currency in a call market. There was a fixed supply of red currency available in each period, and this supply varied according to the treatment. The price-clearing rule was akin to a second-price auction: $k$ units of foreign exchange (red currency) were sold to the highest bidders at the $k+1^{\text {st }}$ bid (denominated in units of green currency). In case of a tie for the $k$-th bid, the fixed supply of foreign exchange was allocated randomly among those tied submitting the marginal bids. The fixed supply of foreign exchange was set equal to the number of subjects less one in the first treatment and the number of subjects less two in the other treatments.

The goods markets were very simple. The experimenter created the supply sides of these markets. The subjects were allowed to buy as much of the green good as they wanted at a fixed price that was announced at the beginning of the session. Likewise, they were allowed to buy as much of the red good as they could afford, at a fixed price that was announced before each period. The only limit on their purchases of the red good had, of course, to do with how much foreign exchange (red currency) they had managed to purchase. Thus goods were in infinitely elastic supply at a price that was announced publicly. In the third treatment, the random price of the red good was determined at the end of the period by a roll of the die, but once that price was determined, red goods were available in perfectly elastic supply at the announced price.

The first treatment analysed purchasing power parity in an essentially static environment. At the beginning of each period, the green-currency price of the green good and the redcurrency price of the red good were announced. The green-currency price of the green good remained constant, while the red-currency price of the red good varied across periods. The subjects were free to purchase either good at the end of each period, but they were not allowed to hold red currency across periods. Thus they had to spend all the red currency they had acquired to purchase red goods at their current price. This aspect of the design was chosen to mitigate any speculative reason to hoard red currency. ${ }^{4}$

The second and third treatments studied interest parity conditions. Each period was divided into to sub-periods, and the currencies bore interest between sub-period A and subperiod B. In both treatments, the interest rate on green currency was always zero, but the

${ }^{4}$ Since the price of the green good never varied, there was no speculative reason to hoard that currency either. 
interest rate on red currency varied from period to period. The interest rate on red currency was always announced before trading for sub-period A began. All red currency had to be spent at the end of sub-period B; this requirement was again chosen to mitigate any motive for hoarding red currency.

In both the second and third treatments, the green currency price of green goods was always constant. In the second treatment, the red-currency price of red goods was also constant, so there was no inflation risk in either currency. In the third treatment, the redcurrency price of the red good was random, but its distribution was very simple. It was distributed as a binomial random variable, with the low price for the red good and the high price for that good both being equally probable.

Each session had two practice periods and ten other periods. Thus in the treatments concerning the interest parity conditions, the foreign exchange market actually cleared 24 times because each period consisted of two sub-periods. The subjects were given sufficient green currency to make for liquid foreign exchange and goods markets in all periods. During the course of the session, their stocks of green currency became smaller, but there was never a point at which any liquidity constraint mattered.

By design, the market for red currency cleared in each period (or sub-period). Since it was impossible to hoard red currency between periods, the subjects never built up a stock of red currency. This aspect of the designs was crucial because it induced a demand for the red currency in each period. This induced demand gives rise to the exchange rate predictions that the hypotheses entail.

Table I gives a summary description of the treatment parameters. It is worth reiterating the general design of the experiment. The first two sessions examined purchasing power parity (the first treatment). ${ }^{5}$ The third session examined covered interest parity (the second

Table I Treatment parameters

\begin{tabular}{|c|c|c|c|c|}
\hline & $5-10-00$ & $10-10-00$ & $13-10-00$ & $20-10-00$ \\
\hline Number of Subjects & 6 & 6 & 6 & 4 \\
\hline $\begin{array}{l}\text { Initial Endowment of } \\
\text { Green Currency }\end{array}$ & 300 & 300 & 500 & 500 \\
\hline $\begin{array}{l}\text { Fixed Supply of Red } \\
\text { Currency }\end{array}$ & 10 & 10 & 4 & 2 \\
\hline $\begin{array}{l}\text { Induced Value of the } \\
\text { Green Good }\end{array}$ & $\$ 0.10$ & $\$ 0.05$ & $\$ 0.05$ & $\$ 0.05$ \\
\hline $\begin{array}{l}\text { Induced Value of the Red } \\
\text { Good }\end{array}$ & $\$ 1$ & $\$ 0.50$ & $\$ 0.50$ & $\$ 0.50$ \\
\hline $\begin{array}{l}\text { Green Currency Price of } \\
\text { Green Good }\end{array}$ & 1 & 1 & 1 & 1 \\
\hline $\begin{array}{l}\text { Red Currency Price of } \\
\text { Red Good }\end{array}$ & $\{0.25,0.5,1,2\}$ & $\{0.25,0.5,1,2\}$ & 1 & $\begin{array}{c}\text { Random on }\{1,2\} \\
\text { with outcomes } \\
\text { equally likely }\end{array}$ \\
\hline $\begin{array}{l}\text { Green Currency Interest } \\
\text { Rate }\end{array}$ & NA & NA & $0 \%$ & $0 \%$ \\
\hline $\begin{array}{l}\text { Red Currency Interest } \\
\text { Rate }\end{array}$ & NA & NA & $\{0 \%, 100 \%, 200 \%\}$ & $\{0 \%, 100 \%, 200 \%\}$ \\
\hline
\end{tabular}

5 The only difference between the first and second session was how much money the subjects could expect to earn. In the first session, the (dollar) redemption value of French bread and German chocolate cake was higher. 
treatment) since there was no uncertainty about the price of either good. The fourth session incorporated price uncertainty for one good and thus examined uncovered interest parity (the third treatment).

It is customary in experimental economics to have at least three or four sessions in each treatment. Since each session uses different subjects, every one is statistically independent, and the fewest sessions that allow for statistically significant inference based upon a (twosided) non-parametric test for two cells is six. It may seem at first paradoxical to an international economist (who is often an applied time series econometrician) that the whole path of asset prices in a session is just one data point. Even though one can see very convincing time-series evidence (across the periods) in each session that the relevant hypothesis under investigation is true, there were not enough sessions in any of the three treatments. I must be forthright and admit that time and budget constraints precluded my running the requisite number of sessions. Since replication is the hallmark of any empirical science, I hope that future experimentalists will run variants of these treatments and discern more closely where simple aspects of the theory of international finance might break down.

\section{EXPERIMENTAL PROCEDURES}

The sessions were held in October 2000 at the Ohio State University. The subjects were undergraduate and graduate students recruited from economics courses. The sessions lasted about ninety minutes, and they were conducted by hand, not by computer. In the first session, the subjects earned between \$US 35 and \$US 40, and they earned about \$US 25 in each of the last three sessions. Almost all the participants found the experiments fun and fairly remunerative. The instructions for the third treatment, the most complicated one, are included in the Appendix. ${ }^{6}$

The instructions make two cash-in-advance constraints very explicit, and they also go into detail about how a call market works. After having read the instructions together aloud, all the subjects answered a series of questions to make sure that they understood the incentives inherent in each design. There was actually very little record keeping required of the subjects because they paid out their green currency and accumulated green and red goods as the session progressed.

The experimenter wrote out the history of prices for the red good on the blackboard, and he also wrote out the prices at which the foreign exchange market cleared. (Namely, the green currency price of a unit of red currency in each period or sub-period.) The currencies were actual play money. The green currency was indeed green, and the red currency consisted of red poker chips. The green currency was called 'marks' and the red currency was called 'francs'?

The green good was called 'German chocolate cake,' and it was represented by round pieces of construction paper that were for sale at the end of every period. The red good was

${ }^{6}$ The instructions for the other treatments can be obtained free of charge by sending email to the author at fisher.244@osu.edu.

7 This experiment was conducted in the United States, where the actual colour of the medium of exchange is indeed green (and only green). Thus the reader ought to be aware that there may have been an 'instinctive preference' for the green money by these subjects. Still, the design made it very clear that green money qua green money was worthless, and it only had value because it could buy German chocolate cake that could in turn be redeemed for actual (American) dollars at the end of the experiment. These 'pieces of cake' were made of bright orange construction paper. 
called 'French bread,' and it was symbolised by oblong pieces of construction paper, again for sale at the end of each period. Every time a transaction was made, a subject spent actual currency to buy goods or foreign exchange. The experimenter was always on the opposite side of each transaction, and goods or red currency was exchange for the green currency with which the subjects had been initially endowed.

The subjects submitted their bids on small chits of paper that were collected and put in rank order. The experimenter was able almost immediately to announce the market-clearing price (the $k+1^{s t}$ bid) for foreign exchange. As is usual with a call market, the inframarginal bids were not made public information. In the case of ties among the marginal bids, there was a public randomisation device (a die) that sorted out who was allowed to buy foreign exchange. All bids for foreign exchange were for equal amounts, either two units in the first treatment or one unit in the second and third treatments.

For the treatments where the red currency bore a rate of return the interest rate was announced before the beginning of sub-period A. Subjects who had purchased red currency during sub-period A were given extra red poker chips, in an amount determined by the red currency interest rate, in time to go shopping at the end of sub-period B. In the third treatment, the price of French bread was random, and it was determined publicly according to a toss of a die. If 1,2 , or 3 came up, the price of French bread was 1 franc. If 4, 5, or 6 came up, the price of French bread was 2 francs.

Finally, a word of caution is warranted for experimenters using call markets. These markets with a fixed supply have very attractive efficiency properties, as the reader shall see below. But, if there are $n$ subjects, it is quite advisable to set $k=n-2$ and thus to sell two fewer units than there are subjects. This is true because having two excluded bids makes the market-clearing price much more robust with respect to small mistakes or to strategic manipulation by the subjects.

\section{Experimental RESUlts}

The results are best summarised by graphs. Figures 1 through 4 show the predictions for each session and the actual data. These figures plot the data including the two initial practice periods in each session. In Figures 1 and 2, the predicted exchange rate is very nearly equal to the actual data. The (minor) exceptions occur at the beginning of the session-when the subjects are learning the mechanism of a call market - and when the predicted exchange rate is near its extreme value. There is some evidence that the subjects are aware of the 'winner's curse' in these markets because the median bids in this treatment were almost never above the predicted value for the exchange rate, even though this treatment was a sixth-price auction. In 24 rounds in the two sessions, the median bid was above the predicted exchange rate only three times; the median bid was never above the predicted exchange rate in the session on 10 October 2000 .

A remarkable aspect of the data summarised in Figures 1 and 2 is that these exchange rates are determined by the lowest of the six bids submitted. Thus the data give very strong evidence in favour of the relative version of purchasing power parity; it seems as though every trader in the market grasp the notion that a high price for red goods entails a weak exchange rate for the red currency. Likewise, the data from the second session in this treatment seem to support the absolute version of purchasing power parity, albeit that the subjects do recognize that there is a strategic element inherent in their bids for foreign exchange. 
5 October 2000

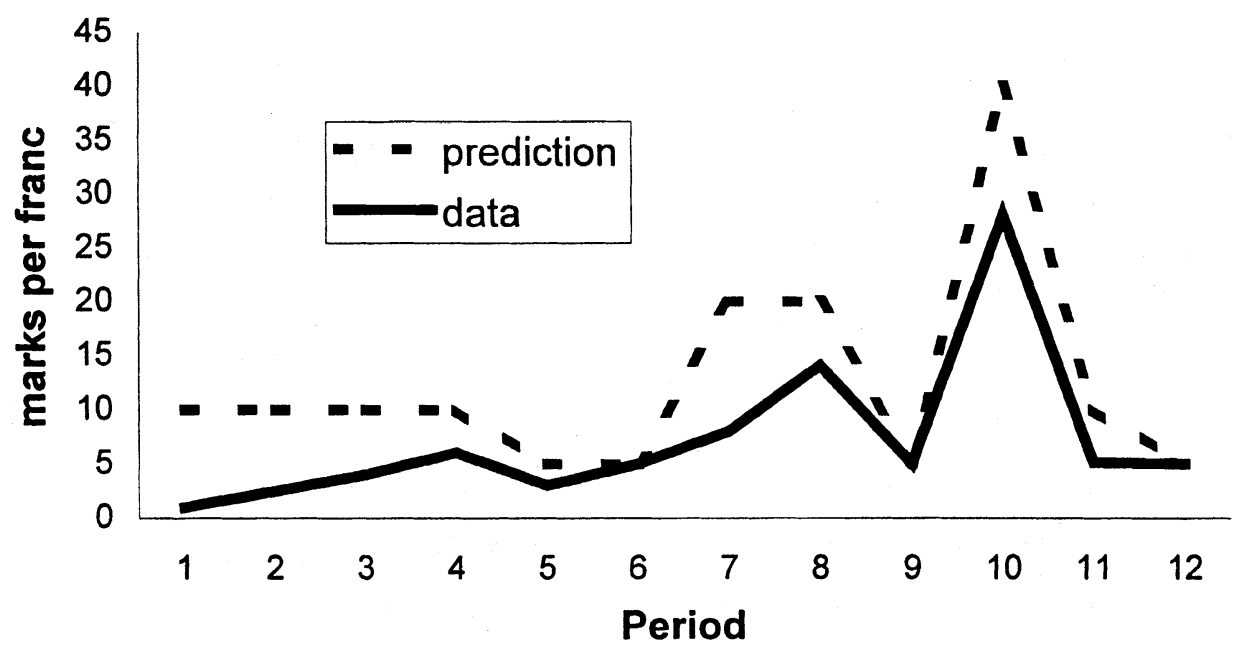

Figure 1. First session

10 October 2000

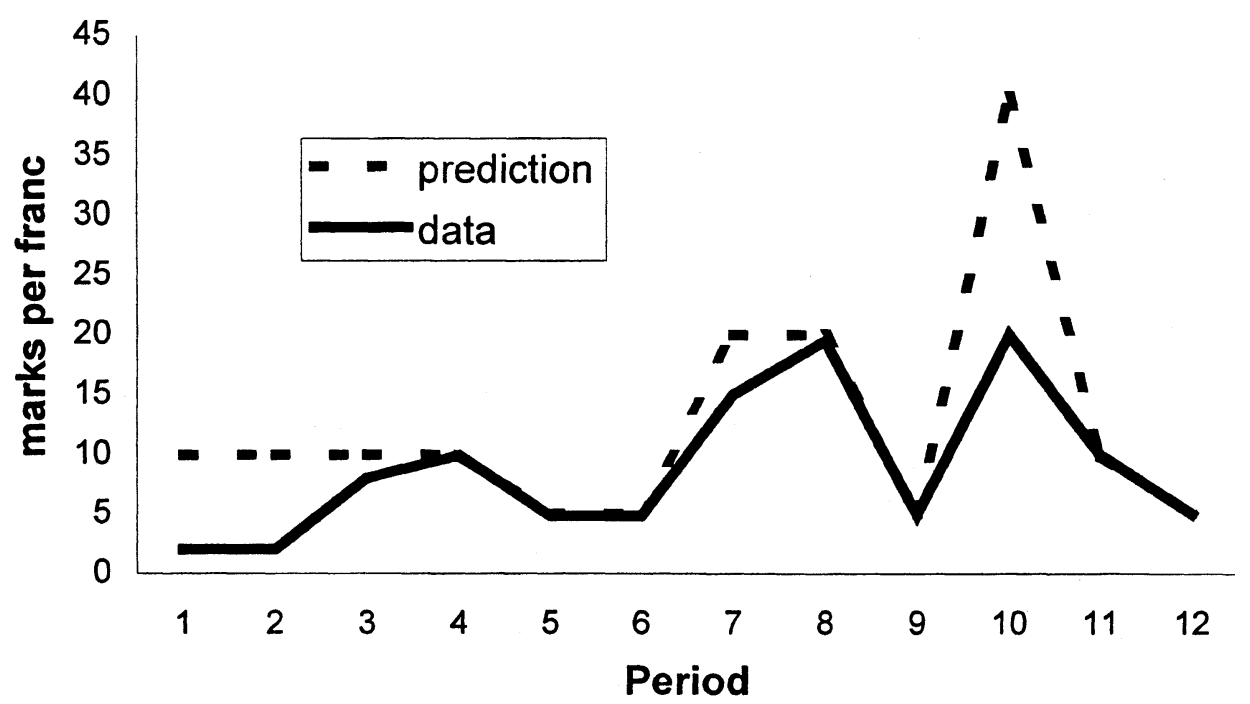

Figure 2. Second session 


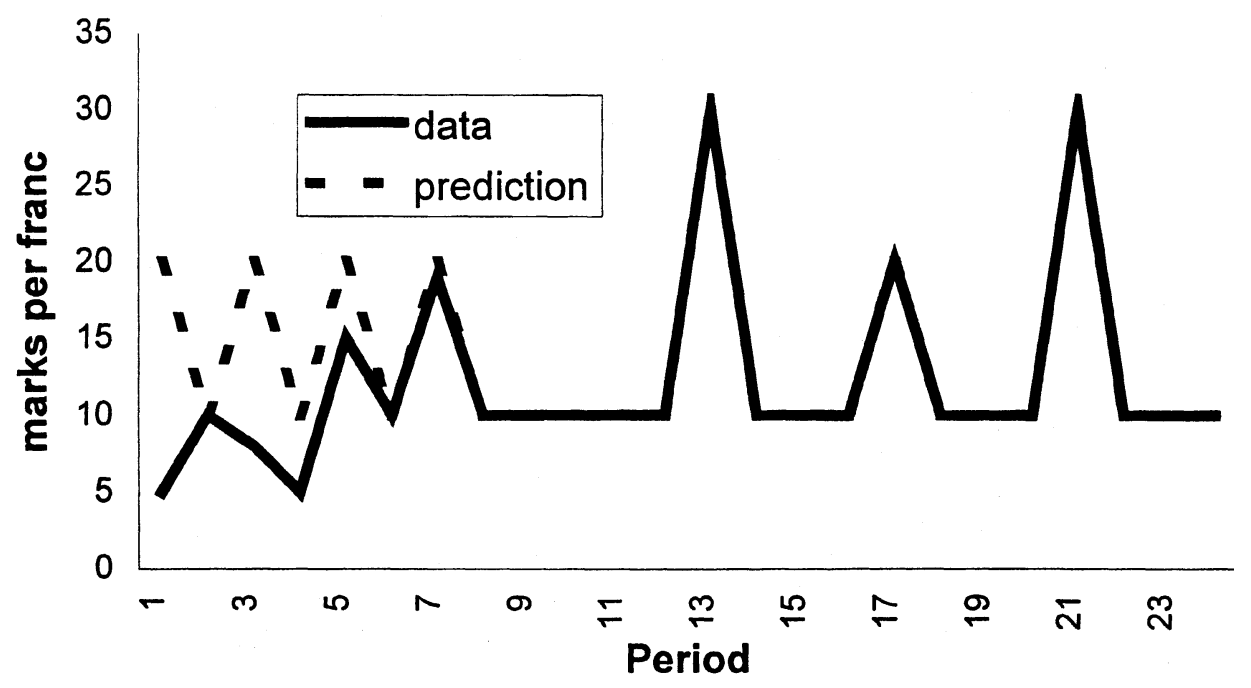

Figure 3. Third session

20 October 2000

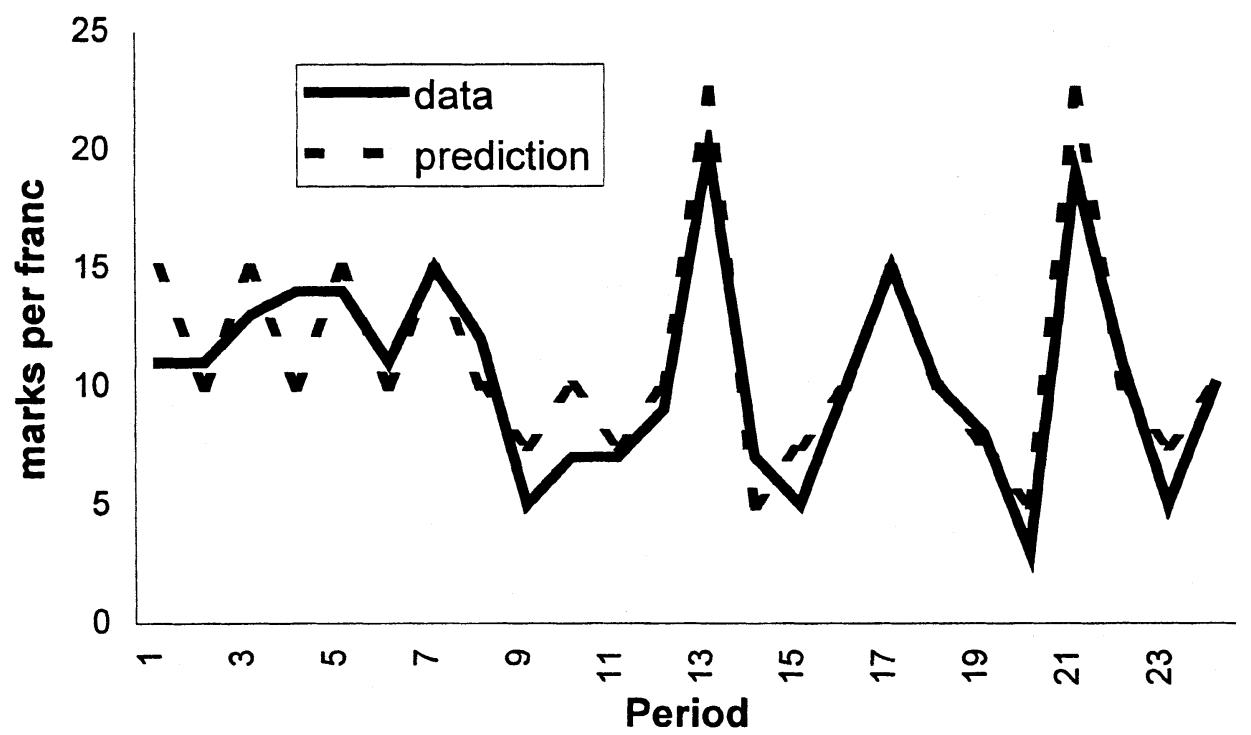

Figure 4. Fourth session 
Figure 3 shows the data for the second treatment, the one that examines covered interest parity. Again, these data included the two practice periods and the other ten periods. Recall that each period in this treatment includes sub-period A and sub-period B; that is why there are 24 observations on the exchange rate in this session. The predicted values for the exchange rate are almost perfectly aligned with the actual data, especially after the initial three periods, during which time the subjects are learning the mechanism of the call market and are coming to understand what it means for the red currency to bear interest. There is some evidence that the subjects understood the winner's curse in these call markets too: there were only two periods in which the median bid was (very slightly) above the predicted value for the exchange rate.

The data in this session fit the theoretical predictions so remarkably well because - even though these are still second-price auctions - only four units of foreign exchange are sold to six subjects. Thus the exchange rate is much more robust to small mistakes by any one subject. It seems very clear that the third treatment lends strong evidence in favour of Hypotheses 1, 2, and 3. Thus the absolute version of purchasing power parity and covered interest parity hold in these markets.

Figure 4 shows the data from the third treatment, the one in which there was inflation risk. Again, the data are a remarkable corroboration of the theoretical predictions. In this treatment, there are twelve periods, each one having two sub-periods; thus there are 24 observations on the exchange rate, including the initial two practice periods. The pattern is familiar by now: after an initial couple of periods in which the subjects learn the mechanism, the data fit the theory almost perfectly. Since there is inflation risk in this treatment, the data indicate that the subjects are largely risk-neutral.

There were only four subjects in this session, and there was some evidence of a winner's curse in these data. Indeed, the median bid exceeded the predicted value of the exchange rate ten times in this session. Of course, the median is sensitive to the marginal excluded bid since there were only four subjects in this session. Still, we are able to conclude with some confidence that the data from this treatment support hypotheses 1,2, and 4; the absolute version of purchasing power parity and uncovered interest parity do hold in these data.

It is instructive to perform a non-parametric test on the degree to which the different exchange rate theories fit the data in these experiments. Recall again that there are really only four independent observations in these data because only four sessions were held. Still, we can analyse how well these data corroborate the theory by looking at the average squared percentage prediction error in each experiment. Let $T(i)$ be the number of data points on the exchange rate generated after the two initial practice rounds in the $i$-th session. (Thus there were 10 data points in the first two sessions and 20 in the last two sessions.) Also, let $y_{t}(i)$ be the $t$-th observation of the exchange rate in the $i$-th session, and let $\hat{y}_{t}(i)$ be its theoretical predicted value. Thus these predictions satisfy all the relevant aspects of the theory: relative purchasing power parity, absolute purchasing power parity, and the relevant version of interest parity. Then

$$
R^{2}(i)=1-\frac{\sum_{t=1}^{T(i)}\left[\left(\hat{y}_{t}(i)-y_{t}(i)\right]^{2}\right.}{\sum_{t=1}^{T(i)}\left[y_{t}(i)\right]^{2}}
$$

is the analog of the usual goodness-of-fit statistic in the $i$-th session. Of course, this statistic 
is based upon a priori theory and does not depend at all upon estimated regression coefficients. Thus it is a very conservative and stringent measure of how well the model fits the data. In a given session, this statistic is near zero if the model fits poorly in every period, and it is near unity if the model is uniformly accurate for every observation. These statistics are independent across sessions because the subjects were different people in each case.

The actual values for these statistics in the sessions on 5 October 2000, 10 October 2000, 13 October 2000, and 20 October 2000 were $0.67,0.68,0.96$, and 0.97 respectively. Even though there are only four independent observations, we can actually construct a confidence interval for the median of this goodness-of-fit statistic. The minimal and maximal values of these realizations give an 87.5 per cent confidence interval for the median fit of the model. ${ }^{8}$ Thus one can be fairly sure that the theory explains between 67 per cent and 97 per cent of variability in the data. (The goodness-of-fit statistics are obviously extraordinarily high in the two treatments where the foreign exchange call market was a third-price auction; the low $R^{2}(i)$ for the first treatment had a lot to do with the fact that the theory missed one extreme observation in each session.) This is accurate indeed for the empirical investigation (across random groups of subjects) of any social scientific theory!

Let us now turn our attention to the kinds of (time series) regressions many international economists run. The typical empirical test of covered interest parity is based upon the following specification

$$
e_{t+1} / e_{t}=\beta_{0}+\beta_{1} f_{t}+u_{t},
$$

where $e_{t}$ is the spot exchange rate (measured in units of domestic currency per unit of foreign currency), $f_{t} \equiv\left(1+i_{t}\right) /\left(1+i_{t}^{*}\right)$ is the discount on foreign exchange one period forward, $1+i_{t}$ is the gross nominal domestic interest rate, $1+i_{t}^{*}$ is the analogous foreign interest rate, and $u_{t}$ is measurement error, perhaps having to do with the advent of news not in the market's information set at time $t$. All these variables are of course measured at the times indicated by their respective subscripts. The use of the actual spot rate in these regressions is justified since actual depreciation should capture expected depreciation on average if the market makes efficient use of all the information available at time $t$. The typical null hypotheses from this kind of regression is that $\beta_{0}=0$ and $\beta_{1}=1$, and it is very rare indeed to find that one does not reject these hypotheses soundly using field data. ${ }^{9}$

The ten periods in each of the last two sessions allow one to calculate measures of depreciation by using the exchange rates in sub-period $\mathrm{A}$ and sub-period $\mathrm{B}$. The estimated coefficients for the above regression obtained using the data from the second treatment (excluding the two practice rounds) are

$$
\begin{aligned}
e_{t+1} / e_{t} & =\underset{(0.045)}{0.056}+\underset{(0.058)}{0.949} f_{t}+u_{t} \\
N & =10, \quad R^{2}=0.985,
\end{aligned}
$$

where the standard are reported in parentheses. Any regression with ten observations is suspect, and the data have already been shown to confirm the theory to such an extent that this regression is an obvious straw man. But it was included here to show how sharp by conventional measures these data are indeed.

8 See Sprent (1989, p. 24), for a discussion of confidence intervals of the median of a distribution. With four observations, the probability that the median is less than the minimal value is $1 / 16$; the probability that it is greater than the maximal value is of course also $1 / 16$.

9 Indeed most such regressions based on bilateral dollar exchange rates find a statistically significant negative estimate of $\beta_{1}$. 
The regression estimated on the analogous data from the third treatment yields

$$
\begin{gathered}
e_{t+1} / e_{t}=\underset{(0.040)}{0.034}+\underset{(0.52)}{1.38} f_{t}+u_{t} \\
N=10, \quad R^{2}=0.467 .
\end{gathered}
$$

Again, the interest differential is a good predictor of the deprecation of the spot exchange rate. This regression has lower $R^{2}$ because the price of the red good in sub-period $\mathrm{B}$ is indeed random. Notice again that one cannot reject either of the typical the null hypotheses for this kind of regression. Thus, using a typical test from the empirical literature in international finance, the data support uncovered interest parity even in a treatment where the red country's 'inflation rate' is random. Indeed, since one cannot reject the null hypothesis that $\beta_{0}=0$ in either of these regressions, there is no evidence of a risk premium in these experimental data, according to the usual test.

\section{Vi. CONCLUSION}

This paper is one of the first analyses of purchasing power parity and interest parity in the laboratory. It analysed three treatments: the first designed to test purchasing power parity, the second focused on covered interest parity, and the third investigated uncovered interest parity. Because the designs were so simple, the data lent strong corroboration to the theory. We found evidence in support of each of the four hypotheses proposed. It is worth reiterating this point. Both the absolute and relative versions of purchasing power parity hold in these data. Covered interest parity finds strong support in them too. And uncovered interest parity also holds in these experiments.

The main element of the designs was that either the green or the red currency had value only by virtue of the goods it could purchase. Thus each design imposed a strong cash-inadvance constraint. The foreign exchange markets were call markets, not the typical interbank over-the-counter market that is predominant in the field. However, there have been historical instances of call markets for foreign exchange, one such example being the traditional foreign exchange fixings in Milan that occurred twice daily.

There is some evidence that the subjects understood the winners curse because the median bid for foreign exchange very rarely exceed the theoretical predicted value. Also, there is no evidence of a risk premium in the third treatment, where holding an open position in red currency was indeed risky.

How can one explain the findings in this paper that appear to be at odds with the overwhelming body of empirical literature based on the econometric analyses of field data? The usual econometric analysis finds that even the relative version of purchasing power parity holds only in the long run if at all. It also finds almost no evidence for the predictive power of the forward premium. There are at least three obvious explanations for why the experiments give much sharper results of the theory. First, the price level in an economy with one good can be measured unambiguously; in field data price indices may not be uniformly accurate measures of the short-term buying power of a currency. Second, these experiments purposely created simple static environments; the advent of information that in financial markets in the field probably creates a non-stationary environment for foreign exchange markets. Third, the properties of a call market in which there is a fixed supply of 
foreign exchange seem to be very efficient; most foreign exchange markets in the field are not organised using one central market-clearing mechanism.

Still, it is clear that in the simplicity of these experiments lies the beauty of their data. Indeed, conducting more experiments to test aspects of the theory of international financial seems a very promising area of future research. Because so much of the empirical literature on international finance seems to hinge upon the statistical properties of different estimators, it seems that many practitioners in this field would welcome the advent of empirical techniques that by their very nature allow for clean and unambiguous statistical inference.

\section{A PPENDIX}

\section{Instructions}

The National Science Foundation has provided the funds for this experiment.

You have been given 500 units of play money. We will call this play money marks. The marks themselves are not worth anything to you, but you can use them to purchase German chocolate cake or to purchase French francs.

At any time, you can purchase as many pieces of German chocolate cake at a price of 1 mark for each piece. That means that we will pay you 5 cents for every piece of German chocolate cake on your desk at the end of the experiment.

During each round, you can trade your marks for francs. The red chips on the front desk are French francs, a different kind of play money. A franc is not worth anything to you, but having francs allows you to buy French bread. The price of French bread is random, according to the inflation rate in France. Still, every piece of French bread on your desk at the end of the experiment is always worth $\$ 0.50$ to you.

The experiment will consist of ten rounds, and each round has two sub-periods, called Sub-Period A and Sub-Period B. You can buy French bread from me at the end of Subperiod B.

The only way you can buy French bread is to go and get some francs. If you have no francs, you can't buy French bread.

In each round, at the end of Sub-period A, I will roll a die. If the die comes up 1, 2, or 3, then there is no inflation in France and price of French bread is 1 franc. If the die comes up 4,5 , or 6 , then there is $100 \%$ inflation in France and the price of French bread is 2 francs. Thus you will know the price of French bread before Sub-period B begins, and you will have a chance to buy more French francs in Sub-Period B if you want to buy French bread.

You carry French francs over from Sub-period A to Sub-period B. But after Sub-period B, you must automatically use all of your francs to buy French bread. You cannot carry francs over from round to round.

German marks don't pay any interest, but French francs pay interest at a rate that I will announce at the beginning of each round, before Sub-period A starts. You earn interest on French franks by buying them in Sub-Period A and holding them until Sub-period B is over. For example, if the interest rate on French francs is $100 \%$, then when you buy one of them in Sub-Period A, you will have 2 of them at the end of Sub-Period B. Likewise, if the interest rate on French francs is $0 \%$, then when you buy 1 of them in Sub-Period A, you will still only have 1 of them at the end of Sub-Period B.

Here's the sequence of events in each round: 
1. I announce the interest rate on French francs;

2. You buy French francs;

3. Your French francs earn interest;

4. I roll the dice to find out what French inflation is and I announce the price of French bread;

5. You buy more French francs; and

6. You buy French bread or German chocolate cake.

Here's how you buy French francs. You bid for them by writing how many German marks you would pay on the order forms I have given you. Once I have collected everyone's pieces of paper, I will put the bids in order, from highest to lowest. This is the demand curve for French francs. I have a fixed supply of 2 francs that I will sell in each sub-period. Where the demand curve crosses the supply curve determines the price of francs. I will announce a price that clears the market. Each person who has bid high enough gets an equal share of these 2 francs at the market price. Thus the two people who bid the highest each get one franc at the market price.

Here's how the market works in greater detail. It is the beginning of sub-period A. I start off by announcing that the interest rate on French francs is $100 \%$, and I remind you that the price of French bread is always one franc. I will announce this at the beginning of the round. Say our four people write down these bids: 18 marks, 21 marks, 17.5 marks, and 19 marks. I will put them in this order: $21,19,18$, and 17.5 . Then I will determine where the demand and supply curves cross.

The supply and demand curves meet at a price of 18.01 marks and a quantity of 2 . Then only two people - those who made the bids 21 and 19 - get to buy the francs. They all pay the same price: 18 marks for a franc. (I drop the extra German penny to make it easy for you and the bank.) The two persons who bid too little - only 18 and only 17.5 - have to wait until next sub-period if he or she wants to buy a franc. Each of the other two people gets one franc and uses up 18 marks to buy it.

In case of a tie among the second lowest bids, I will randomly pick a person who gets shut out of the market for francs. I will roll some dice to see who gets shut out of the market.

If you have managed to buy a franc, then you know that your franc will earn $100 \%$ interest. So by the end of sub-period B, your franc will turn into two francs. I will give you an extra franc (or red chip) on your desk at the end of Sub-Period B.

Now I roll the dice, and 2 come up. So there has been low inflation, and the price of French bread is only 1 franc. Now the market for French francs opens up again.

During sub-period B, I will again sell a total of two francs, using exactly the same mechanism. Say this time our four people write down these bids: 10 marks, 11 marks, 7 marks, and 8 marks. I will put them in this order: 11, 10, 8, and 7. Now the supply and demand curves meet at a price of 8.01 marks and a quantity of 2 . Then only two people those who made the bids 11 and 10 - get to buy the francs. They all pay the same price: 8 marks for a franc. (Again I drop the extra German penny to make it easy for you and the bank.) The two persons who bid too little - only 8 and only 7 - have to wait until the next round if they want to buy francs. Each of the other two people gets one more franc and uses up 8 marks to buy it.

Once sub-period B is over, the baker will come around, and you can buy German chocolate cake or French bread. Remember, German chocolate cake always costs one mark and French bread costs one or francs, depending on inflation in France.

Are there any questions? 


\begin{tabular}{|c|c|c|c|c|c|}
\hline \multirow[b]{2}{*}{ Round } & \multicolumn{2}{|c|}{ Sub-Period A } & \multirow{2}{*}{$\begin{array}{c}\text { Franc } \\
\text { Interest } \\
\text { Rate }\end{array}$} & \multicolumn{2}{|c|}{ Sub-Period B } \\
\hline & Marks left & My bid for francs & & Marks left & My bid for francs \\
\hline 00 & 500 & & $100 \%$ & & \\
\hline 0 & 500 & & $100 \%$ & & \\
\hline 1 & 500 & & $100 \%$ & & \\
\hline 2 & & & $100 \%$ & & \\
\hline 3 & & & $0 \%$ & & \\
\hline 4 & & & $0 \%$ & & \\
\hline 5 & & & $200 \%$ & & \\
\hline 6 & & & $0 \%$ & & \\
\hline 7 & & & $100 \%$ & & \\
\hline 8 & & & $0 \%$ & & \\
\hline 9 & & & $200 \%$ & & \\
\hline 10 & & & $0 \%$ & & \\
\hline End & & & & & \\
\hline
\end{tabular}

GERMAN CHOCOLATE CAKE IS WORTH 5 CENTS

FRENCH BREAD IS WORTH 0.5 DOLLAR

Short quiz

1. The price of French bread is 2 francs per piece. You have no francs. How many pieces of bread can you buy? pieces of French bread

2. The price of French bread is 1 franc per piece. You have 3 francs. How many pieces of bread can you buy? pieces of French bread

3. If you do buy 3 pieces of French bread, how much money will you get when you redeem them at the end of the experiment? dollars 
4. You bid 21 marks for a franc. After analysing supply and demand, I announce that the market price for a franc is 18 marks per franc. Do you get to buy a franc?

5. You bid 21 marks for a franc. The market price for a franc is 18 marks per franc. How much do you actually pay for a franc? marks

6. You started the experiment with 500 marks. After paying 18 marks for a franc, how many marks do you have left? marks

7. You bid 17 marks for a franc. After analysing supply and demand, I announce that the market price for a franc is 18 marks per franc. Do you get to buy a franc?

8. You have bought 1 franc in sub-period A. The interest rate on French francs is $100 \%$. How many francs will you have at the end of sub-period B? francs

9. You have bought 1 franc in sub-period A. The interest rate on French francs is $0 \%$. How many francs will you have at then end of sub-period B? francs

10. You have bought 1 franc in sub-period A. The interest rate is $200 \%$. The price of French bread is 1 franc. How many pieces of French bread will you be able to buy at the end of sub-period B? pieces

11. How much money will you receive at the end of the experiment if you have 40 pieces of French bread and 200 marks? dollars

12. What happens if two people both bid 17 francs, and this is the second lowest bid? Professor Fisher will randomly shut out one person from the franc market by rolling some

\section{REFERENCES}

Arifovic, J. 1996, 'The Behavior of the Exchange Rate in the Genetic Algorithm and Experimental Economies', Journal of Political Economy, vol. 104, pp. 510-541.

Cassel, G. 1916, 'The Present Situation of the Foreign Exchanges', Economic Journal, vol. 26, pp. $62-65$.

Engle, R.F., Ito, T. and Lin, W.-L. 1990, 'Meteor Showers or Heat Waves? Heteroskedastic IntraDaily Volatility in the Foreign Exchange Market', Econometrica, vol. 58, pp. 525-542.

Fisher, E.O'N. forthcoming, 'Experiments with Arbitrage across Assets', in C. Plott and V. Smith, eds. Handbook of Experimental Economic Results.

Fisher, E.O'N. and Kelly, F. S. 2000, 'Experimental Foreign Exchange Markets', Pacific Economic Review, vol. 5, pp. 368-388.

Noussair, C., Plott, C. and Riezman, R. 1997, 'The Principles of Exchange Rate Determination in an International Finance Experiment', Journal of Political Economy, vol. 105, 822-61.

Sprent, P. 1989, Applied Nonparametric Statistical Methods, Chapman and Hall, London. 